\title{
Industrial Development in Fisheries Based on Blue Economy of Tominy Bay
}

\author{
Eduart Wolok $^{\mathbf{a}}$, Lis M Yapanto ${ }^{\mathbf{b}}$, Abdul Hafidz Oliib., Funco Tanipu ${ }^{\mathbf{c}}$

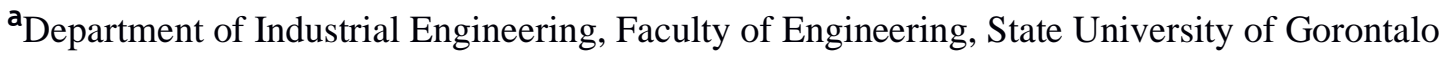 \\ ${ }^{b}$ Faculty of Fisheries and Marine Science. State University of Gorontalo \\ ${ }^{\mathrm{c}}$ Department of Sociology, Faculty of Social Science, Gorontalo State University \\ Correspondent author*: lizrossler@ung.ac.id
}

\begin{abstract}
The participatory prospective analysis aims to determine critical variables in the development of the sustainable fishing industry according to the blue economy concept-a further study in management policy. The fishery management in Fish Landing Ports and Fish Halls has not applied the blue economy approach yet, thus its waste utilization. The participatory prospective analysis approach in determining the management policy by organizing consignment by relevant stakeholders such as Department of Marine and Fisheries of Gorontalo Province, Department of Marine and Fisheries of Gorontalo City, Chief Operating of PPI Tenda Gorontalo City, Fishery industry, fishermen of Gorontalo City and TPI (Fish auction) Gorontalo City. The is symbolizes four main variables of policymaking: environmentally friendly, cooperation in togetherness, industrial increase, and zero waste.
\end{abstract}

Keywords: participatory, prospective analysis, skipjack, blue economy, tuna fisheries industry, fisheries waste, tuna mackerel.

\section{Introduction}

The waters of Gorontalo Province have great capture fisheries potential. Based on data from Gorontalo Province in 2019 (Anonymous, 2012), data on the catch of tuna 4,796.3 tons, tuna 4,642.2 tons, and skipjack 5,633.8 tons. The most common types of tuna are yellowfin / Thunnus albacares and bigeye (Thunnus obesus) tuna. The dominant tuna are krai and Komo / kawakawa mackerel (Euthynus affinis).

From field observations, the authors conducted interviews at the TPI (Fish auction) with the captain and fishers from the Pristi Ship, which functions as a trolling fishing boat. Interview results of fishers catching tuna in December 2019 traditionally using a boat weighing 8 GT, ruaya (fishing operation) around the coast with one week sailing day with the catch of most of the juvenile tuna (yellowfin tuna) and bigeye/bigeye tuna. The body length of the juvenile yellowfin tuna saplings caught has an extended range of $29-65 \mathrm{~cm}$, the medium length with the mode at the mean $38 \mathrm{~cm}$. Fish catch conditions in PPI (Fishing Port) based on statistical data in 2018 the number of catches bigeye tuna/bigeye tuna 632.12 tons, yellowfin tuna/yellowfin tuna 480.03 tons, skipjack tuna 428.30 tons. The catch of little eastern tuna is 33.80 tonnes, frigate tuna is 70.57 tonnes, and longtail tuna is 10.78 tonnes. PPI is a landing place for catching tuna and skipjack using a long tuna line, purse seine, and troll line with routes up to the Indonesian Ocean included in the fisheries management area WPP 715 (Anonymous, 2015). The catch of tuna weighs more than $50 \mathrm{~kg}$ (Anonymous, 2012b).

According to production theory, there are four stages of natural resource production regarding input use (Anderson, 1986; Susilowati, 2006). Phase I is a production that can achieve maximum economic gain (profit) MEY. Stage II, a production that can reach the maximum amount of physical production MSY, stage III, a production that does not gain or lose (break-even point or open access), stage IV is loss-making production.

In the Regional Medium-Term Development Plan (RPJMD), Gorontalo City 2010-2016 can produce sizeable pelagic fish (tuna, skipjack, mackerel, and mackerel) the waters of Tomini Bay. For the west of Pohuwato and Boalemo Regencies, which can be done with sustainable fishing with a maximum production of 46,190 tons/year, with a sustainable fishing production rate of 50\% (Anonymous, 2008).

In this regard, in fishing, it is necessary to pay attention to Law 31 of 2004 Chapter IV Article 6 concerning Fisheries Management, paragraph 1, it that fisheries management in the Republic of Indonesia is carried out to achieve optimal and sustainable benefits, as well as to ensure the quality of fish resources. Based on Ministerial Decree No.45 / Men / 2011 in Appendix 2, which types of fish can still be caught, including skipjack tuna in moderate condition, Big Eyes, and Madidihang are fully exploited. The Big Eye Tuna is overexploited, which means Big Eye Tuna is over-exploiting the sea but not balanced by cultivation or regeneration. Albacore Tuna types can still be caught because they are in suitable conditions and were arrested. It is known that the large pelagic fisheries in Tomini Bay waters that can be caught temporarily are skipjack and albacore.

The catch of fish at TPI Gorontalo City is tuna tillers which can affect the growth and reproduction of fish, causing a decrease in fishery resources (Gjertsen, H., Hall, M., and Squires, D., 2010). Therefore an approach is 
needed in fisheries management, including tuna fisheries, that consider the sustainability of fisheries resources. The participatory prospective analysis is an approach that puts forward a participatory process and can provide agreement (consensus) between stakeholders (Godet and Roubelat 1996; Bourgeois and Jesus 2004; Gray and Hatchard. 2008; Godet 2010; Human and Davies, 2010). Thus the various interests of stakeholders can be bridged in developing a sustainable capture fisheries industry, according to the concept of the blue economy.

The blue economy is an economic system based on the principles of sustainable natural resource management. An efficient and clean production system supports it without damaging the environment for the welfare of humanity today and in the future. The blue economy has three interests, namely economic growth, community welfare, and environmental health. The blue economy can be an economic development that relies on marine resources that are massively associated with sustainable management and asset preservation (Gunter, 2010).

It is necessary to conduct research that applies Participatory Prospective Analysis to develop a sustainable fisheries industry, following the concept of a Blue Economic based on Large Pelagic Fisheries in Tomini Bay Waters. In this research, we want to know the key variables in the development of the fishing industry by blue economy policies. The optimal solution according to the practical policy adopted. The operations differences are very marked in terms of allocation of products and the number and size of batches to satisfy the customer requirements

(Ackermanna et al., 2020).

\section{Research Method}

The research location is around the waters of Tomini Bay Gorontalo Province (Figure 1). In this study, faceto-face with fishers in Gorontalo City and Pohuwato Regency in March until Juny 2019. conducted a participatory prospective analysis used in decision making.

The participatory prospective analysis is designed to seek and anticipate change with experts and stakeholders. The results of the analysis release quick information that can be used by fellow participants so that policies in development can be obtained. The number of participants who attended was 15 people, including fishers from Gorontalo City. Government and private decision-makers such as the Marine and Fisheries Office of Gorontalo City, Gorontalo Province, PPI Gorontalo City and PPI Pohuwato Regency are under the Directorate of Fisheries Port, Directorate General of Capture Fisheries, Ministry of Marine Affairs and Fisheries, and the Coordinating Board for Planting Capital (BKPM) of Gorontalo Province. Participants from the private sector are PT Tuna Loin, engaged in exporting fresh tuna to Japan and exporting processed tuna to Singapore, Hongkong. The analysis stages are shown in Table 1.

Figure 1. The research location is around the waters of Tomini Bay Gorontalo Province

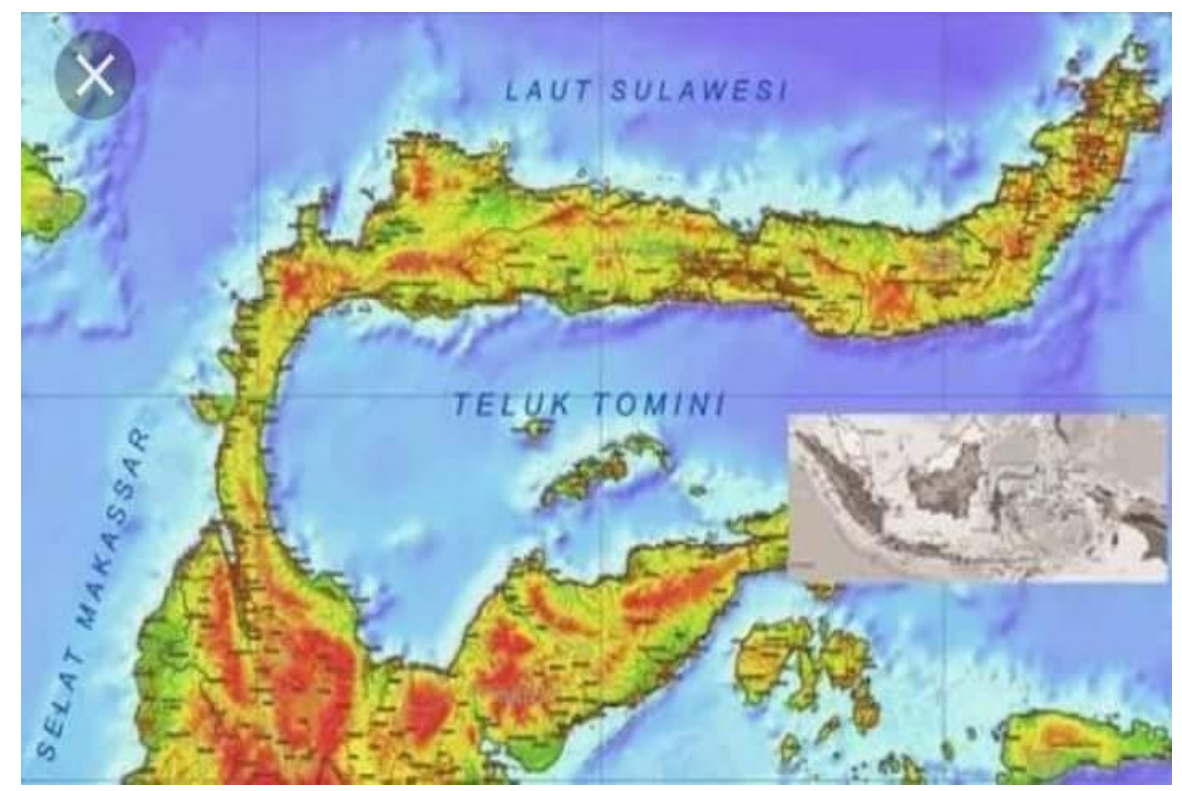

Sumber: https://www.funco.id/teluk-tomini-yang-terabaikan/

\section{Result and disscusion}

\section{Participatory Prospective Analysis for Determination of Key Variables}

During the meeting, experts or participants were asked to identify the key variables that are considered the most influential on the blue economy policy of large pelagic fisheries in the waters of western Sumatra. Based on these parameters, problem identification is carried out by dividing it into six domains with subdomains so that the variables that need to be observed are 25 variables (Table 2).

The variables in Table 2 were identified into 14 key variables and their definitions (Table 3 ).

The variables in Table 3 are the results of the discussion and consensus reached by the participants. In this case, it is unknown which variable most determines in the formulation of the blue economy policy model. The influence 
between variables cannot, so all variables have the same importance and power to the system. On the other hand, it is necessary to know the difference in the level of influence of variables to determine the variables that need to as entry points for effective planning (Godet and Roubelat, 1996; Bourgeois and Jesus, 2004; Gray and Hatchard, 2008; Godet, 2010; Peace, 2012).

\section{Analysis of Influence Between Key Variables}

\begin{tabular}{cll}
\hline No. & \multicolumn{1}{c}{ Stages } & \multicolumn{1}{c}{ Approach } \\
\hline 1 & System determination / definition & Initial preparation and group discussion \\
2 & Variable identification & Brainstorming \\
3 & Key variable definition & Structured group discussion \\
4 & Analysis of the influence between variables & Structural analysis and group work \\
5 & Interpretation of influence and dependence between & Group discussion supported by graphs and analysis \\
& variables & results tables \\
6 & Defining the future condition of the variable. & Morphological analysis and group discussion \\
7 & Scenario building & Brainstorming \\
8 & Formulation of strategic implications and anticipatory & Structured discussion \\
& action & \\
\hline
\end{tabular}

Based on the 14 variables in Table 3, the participants returned to the discussion. They consensually gave scores on the cross-influence between variables, which were analyzed matrix with the help of Excel software (Bourgeois and R., and Jesus, F., 2004.).

Table 1. Participatory prospective analysis stage

\begin{tabular}{|c|c|c|}
\hline No. & Variable & Domain \\
\hline 1 & Cooperation & Social capital \\
\hline 2 & Customary law & \\
\hline 3 & Coastal community empowerment & \\
\hline 4 & Fisherman behavior in fishing (culture) & \\
\hline 5 & Fisherman character & \\
\hline 6 & Fishing facilities at TPI Tenda & Innovation \\
\hline 7 & Fishing facilities at PPI Tenda & \\
\hline 8 & Fish port facilities at TPI Kabupaten Pohuwato & \\
\hline 9 & Fish port facilities at PPI Kab. Kabupaten Pohuwato & \\
\hline 10 & Remote sensing technology for capture fisheries & \\
\hline 11 & Source of fishermen's capital & Limited investment \\
\hline 12 & Transportation services & \\
\hline 13 & Fishing facilities & \\
\hline 14 & Port facilities & \\
\hline 15 & Master of the ship & Employment Opportunity \\
\hline 16 & Ship Crew (ABK) & \\
\hline 17 & Fisherman & \\
\hline 18 & Tuna quality checker & \\
\hline 19 & Factory workers & \\
\hline 20 & $\begin{array}{l}\text { The waste from a product will become material for } \\
\text { another product }\end{array}$ & Leaving no waste \\
\hline 21 & Leaving no waste & \\
\hline 22 & Environmentally friendly & \\
\hline 23 & Industrial upgrading & Entrepreneurship \\
\hline 24 & Feed innovation & \\
\hline 25 & Human Resources & \\
\hline
\end{tabular}


Table 2. The participants identified the influencing variable.

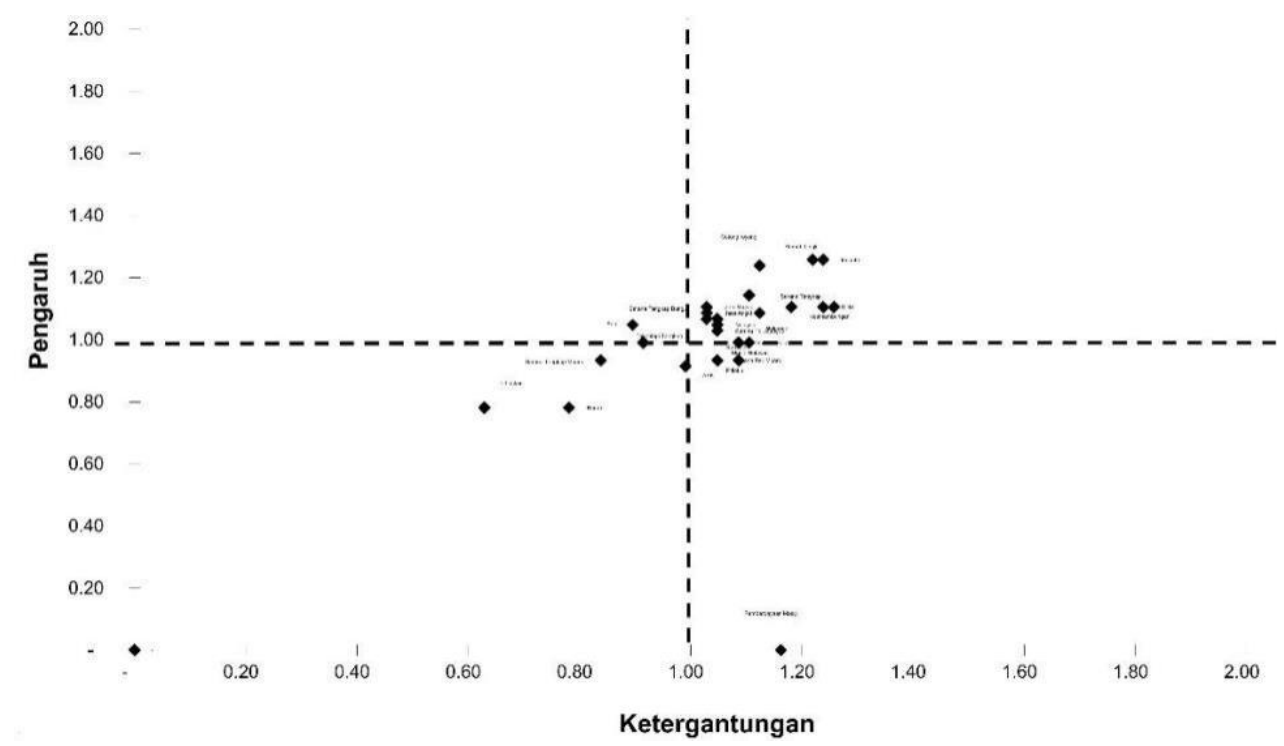

Figure 2. The results of the analysis of the direct effect between variables.

In practical terms, direct effect analysis consists of valuing the direct effect of one variable on another, using a scale from " $0=$ no effect" to " $3=$ very strong effect". scores discussed and agreed upon by the participants are directly included in the I/D matrix. The analysis results of the influence between variables are presented in graphs and tables in Figure 2. Each quadrant relates to the specific characteristics of the variable. Quadrant I (top left) is the variable driving region. Quadrant II (top right) is the control variable area (leverage) characterized by substantial influence and dependence; some of the variables in this quadrant can also be classified as concrete variables. Quadrant III (bottom right) is the output variable area, highly dependent, and has little influence. Quadrant IV (bottom left) represents the marginal (marginal) variable region; this group will be immediately excluded from the analysis.

Table 3. The influence variable was identified and defined by the participants.

Apart from the four quadrants, there is also a gray area along the axis that separates quadrant IV from the other quadrants. There may be a group of variables in the gray area whose role in the system cannot. From the presentation of the analysis of the direct and indirect (total) effects shown in Figure 2, 4 variables 
can be selected, which can be said to be the most influential variables, namely environmentally friendly, cooperation, industrial improvement, and leaving no waste. The supported by the value of the weighted global power of each variable, where the four variables have a higher value than the other ten variables (Table 5). From

\begin{tabular}{lll}
\hline No. & Domain & \multicolumn{1}{c}{ Variable } \\
\hline 1 & Social capital & Cooperation \\
2 & & Customary law \\
3 & & $\begin{array}{l}\text { Fisherman behavior in fishing } \\
\text { (culture) }\end{array}$
\end{tabular}

4 Innovation

5

6

7 Limited investment Source of fishermen's capital

8

$9 \quad$ Employment

Opportunity

10 Leaving no waste

11

13 Entrepreneurship
Fishing facilities at TPI Pohuwato Regency

Fishing facilities at TPI Tenda Gorontalo City

Remote sensing technology for capture fisheries Transportation services

Master of the ship

Waste from one product will become material for other products

Leaving no waste

Environmentally friendly

Industrial upgrading
Definitions and descriptions

All In Gorontalo Province every

month

Application of customary law in management and capture fisheries conservation

The knowledge of fishers in catching tuna, skipjack using environmentally friendly fishing rods (hand lines) as well

pay attention to the fish caught according to fish weight and age

Fishing facilities need to be improved through the assistance of the local government as well as from groups

fisherman

Fishing facilities need to be improved through the assistance of the local government as well as from groups

fisherman

Remote sensing can help capture fisheries in

determining the location of the catch,

catch season

Sources of capital for private or group fishermen

The available fleet can be sufficient for

transport of catches

Lack of interest and skills to become

skipper

The process in the management of tuna centers mus1 consider sustainability, where the output of a process can be made input for other processes

The tuna waste produced can be used as feed ingredients, fish meal, or other processed products The capture process and the industry must consider the environment in which exhaust gas emissions and other pollution to the environment must be reduced Industry or business actors involved in efforts to improve the management and marketing of tuna that are legally managed by the private or government industries that think about it continuity.

Human Resources (HR)
The capacity of graduates and the managerial skills of human resources who are educated and specially trained in the field

fishing to fish management tuna.

results of this analysis, it can be concluded that the variables number 1 to 4 chosen as the most influential variables (Godet and Roubelat, 1996; Bourgeois and Jesus, 2004).

\section{Scenarios Development}

The scenario development in Table 6 through brainstorming and structured group discussions. In the forum, participants were asked to provide estimates of the conditions of each determining variable in the future. This estimate is an opinion and a reflection of the future needs of stakeholders (Godet and Roubelat, 1996; Bourgeois and Jesus, 2004; Gray and Hatchard, 2008; Coates et al., 2010; Durance and Godet, 2010). From the estimates regarding the condition of these variables in the future, scenarios that might occur in PPI can be prepared Gorontalo City.The participants' brainstorming from the consensus used to prepare possible scenarios for the capture fisheries industry development in the research area is presented in Table 7. 
Table 5. Weighted global variable power score.

\begin{tabular}{llc}
\hline No. & Variable & The power of weighted global variables \\
\hline 1 & Environmentally friendly & 1,1986 \\
2 & Cooperation & 1,2461 \\
3 & Industrial upgrading & 1,2961 \\
4 & Leaving no waste & 1,1327 \\
5 & Master of the ship & 1,0264 \\
6 & Remote sensing technology for capture fisheries & 1.0356 \\
7 & Fishing facilities at PPI Tenda Gorontalo City & 1.0119 \\
8 & Transportation services & 1.0476 \\
9 & Fishing facilities at TPI Pohuwato Regency Gorontalo & 1.0107 \\
10 & Fisherman behavior in fishing (culture) & 1,0142 \\
11 & The waste from a product will become material for & 1.0108 \\
& another product/sustainability & 1.0003 \\
12 & Source of fishermen's capital & 1.0004 \\
13 & Human Resources (HR) & 0.4532 \\
14 & Customary law &
\end{tabular}

Source: Primary data, 2019.

Table 6. The participants, by consensus, determine variable conditions.

\begin{tabular}{lcccccc}
\hline Variable & \multicolumn{7}{c}{ Possible conditions occur } \\
\cline { 2 - 7 } & Code & 1 & 2 & 3 & 4 & 5 \\
\hline Environmentally friendly & A & A1 & A2 & A2 & A3 & A4 \\
Cooperation & B & B1 & B1 & B2 & B2 & B2 \\
Industrial upgrading & C & C1 & C1 & C2 & C2 & C2 \\
Leaving no waste & D & D1 & D1 & D2 & D2 & D2 \\
\hline
\end{tabular}

Note: Condition $1=$ getting worse; $2=$ remains as it is; $3=$ increase with limited progress; $4=$ improved well and 5 = ideal conditions. Source: Primary data, 2019.

Table 7. Sustainable capture fisheries development scenarios.

\begin{tabular}{|c|c|c|}
\hline Condition & Selected variable & Information \\
\hline It got worse & A1-B1-C1-D1 & $\begin{array}{l}\text { A1: Environmentally friendly is not applicable, B1: mutual cooperation } \\
\text { will weaken C1: The industry remains what it is today } \\
\text { D1: Zero waste / leaving no waste is not applied }\end{array}$ \\
\hline Stay like now & A2-B1-C1-D1 & $\begin{array}{l}\text { A2: Environmentally friendly will change for the better B1: mutual } \\
\text { cooperation will get weaker. } \\
\text { C1: The industry remains what it is today } \\
\text { D1: Zero waste / leaving no waste is not applied }\end{array}$ \\
\hline $\begin{array}{l}\text { Increases with limited } \\
\text { progress }\end{array}$ & A2-B2-C1-D1 & $\begin{array}{l}\text { A2: Environmentally friendly will change for the better B2: mutual } \\
\text { cooperation institutionalized. } \\
\text { C1: The industry remains what it is today } \\
\text { D1: Zero waste / leaving no waste is not applied }\end{array}$ \\
\hline Improved well & A3-B2-C2-D2 & $\begin{array}{l}\text { : Environmentally friendly will be further increased, followed by law } \\
\text { enforcement. } \\
\text { B2: Gotong royong will be more institutionalized. C2: The industry is } \\
\text { progressing and developing } \\
\text { D2: Zero waste / leaving no waste is not applied }\end{array}$ \\
\hline Ideal conditions & A4-B2-C2-D2 & $\begin{array}{l}\text { : Environmentally friendly will be further increased, followed by } \\
\text { incentives. } \\
\text { B2: Gotong royong will be more institutionalized. C2: The industry is } \\
\text { progressing and developing } \\
\text { D2: Zero waste / leaving no waste is not applied }\end{array}$ \\
\hline
\end{tabular}

Source: Primary data, 2019. 
Table 8. Changes in fishing behavior in Gorontalo Province.

Done now

Catch fish around FADs

Fish caught by juvenile juveniles are underweight $50 \mathrm{~kg}$

They caught fish in the fish hold stored piled up, causing the fish that is located at the bottom from fiber (Idris., 2012)

to rot

There is no recording of fishing (log book), the recording is done on land

Source: Primary data, 2019.

Table 9. Changes in fishing behavior at PPI Tenda, Gorontalo City

\begin{tabular}{ll}
\hline Done now & Treatment suggestions \\
\hline The fins and coccyx are not used & Can be made fish meal as animal feed \\
Purse seine fishing & Using a fishing rod \\
\hline
\end{tabular}

Source: Primary data, 2019.

\section{Strategic Implications and Anticipatory Action}

The strategic implications and anticipatory actions that participants can formulate are to prepare themselves to face situations in the future (pro-active), which also prepares a re-active action. Through scenario identification and comparison, decision-makers and stakeholders can better plan the future of a region (Godet and Roubelat, 1996; Bourgeois and Jesus, 2004; Gray and Hatchard, 2008; Coates et al., 2010; Durance and Godet., 2010).

Blue Economy can be seen as an action that rests on the comprehensive development of the people's economy in order to achieve national development as a whole. The blue economy-based development approach will synergize with the implementation of a triple track strategy, namely pro-poor programs (poverty alleviation), pro-growth (growth), pro-jobs (absorption of labor), and pro-environment (preserving the environment).

The participatory prospective analysis produces four main variables: environmentally friendly, cooperation, industrial improvement, and leaving no waste. The application of the four policy model variables needs to be applied at TPI Grontalo City and PPI Tenda as listed in Tables 8 and 9.

\section{Conclusion}

The fishing for tuna and skipjack in the waters of Tomini Bay (Gorontalo City) is different from that in PPI In Pohuwato Regency, the fishermen use troll fishing boats. They are catching around FADs with the catch of tuna chicks weighing under $50 \mathrm{~kg}$. The type of tuna obtained is fin tuna and to meet the supply of fish canning factories. Yellow/yellowfin and bigeye tuna. The catch in the hold can cause the tuna at the bottom layer to rot. Such treatment needs by redesigning the hatch. To get tuna catches above $50 \mathrm{~kg}$, the fishermen catch tuna outside the FAD area.

The tuna and skipjack fishing system at PPI Tenda Gorontalo city using tuna longlines, purse seines, and trolling lines. The use of purse seines is not environmentally friendly because it can interfere with the sustainability of the tuna population and protected biota.

Not all processed tuna products can be utilized, such as wasted tuna fins and tailbone. With the right technology, the fin and tailbone can of fish meal for animal feed.

\section{Acknowledgment}

The field data used in this study came from research activities funded by the Gorontalo Province Regional Development Planning Agency. Therefore the authors would like to thank the Head of the City Development Planning Agency, Gorontalo. 


\section{References}

Alberti, M. (2010). Maintaining Ecological Integrity And Sustaining Ecosystem Function In Urban areas. DOI: https://doi.org/10.1016/j.cossut. 2010.06.007

Aryani, F. (1994).Analisis Kerja dan Kontribusi Penerimaan Keluarga Nelayan dalam Kegiatan Ekonomi di Desa Pantai: Studi Kasus di Desa Pasisr Baru Ke. Cisolok Kabupaten Sukabumi. IPB Bogor.

Arifiani, N. A., \& Mussadun, M. (2016). Studi Persepsi Masyarakat terhadap Tingkat Keberlanjutan Wilayah Pesisir Kecamatan Sarang. Jurnal Wilayah Dan Lingkungan, 4(3). https://doi.org/10.14710/jwl.4.3.171-186

AryonoB. (2004).Kajian Peran Pengembangan Pariwisata BahariTerhadap Kesejahteraan Nelayan. Pasca Sarjana UndipSemarang

Ayob, A.M. (1979). Teori Mikro Ekonomi Dewan Bahasa dan Pustaka Kuala Lumpur Badan.

Badan Perencanaan dan Pembangunan Daerah Kabupaten Bone Bolango. (2006).Penyusunan Master Plan Pengembangan Perikanan Laut dan Darat ProvinsiGorontalo. Bappeda Kabupaten Bolango

Brunbjerg, AK., Borchsenius, F., Eiserhardt. W, L et al., (2012a) Disturbance drives phylogenetic community structure in coastal dune vegetation. J Veg Sci23:1082-94.

Baharsyah, S. (1990). Peluang Usaha Yang tetap Luas di Sektor pertanian Prisma No 2 hal 86LP3S

Bengen, D.G. (2000). Penentuan dan Pengelolaan Kawasan Lindung di Pesisir, Laut dan Pulau-Pulau Kecil. Makalah Lokakarya. Direktorat Jenderal Pesisir, Pantai dan Pulau-pulau Kecil. Departemen Kelautan dan Perikanan RI. Jakarta.58 hal.

Bishop, Richard and Richard Woodward. (1995).Valuation of Enviromental Quality Under Certenity , In:D.Bromley (eds) The Handbook of Environmental Economics. Blackweel Publishing, Oxford

Biso, J., Andaki, J. A., \& Manoppo, V. E. N. (2017). DIVERSIFIKASI USAHA RUMAH TANGGA NELAYAN. AKULTURASI (Jurnal Ilmiah Agrobisnis Perikanan), 5(10). https://doi.org/10.35800/akulturasi.5.10.2017.18827

Budiharso, S. (2001). Teknik Analisis Pembangunan Wilayah Pesisir dan Laut. Penerbit Pradya Paramita Jakarta

Brown, Maxwell L. (1979). Farm Budgets, From Farm Income to Agricultural Project Analysis. The John Hopkins University Press. Baltimore and London

Chambers, R. (1991).Shortcut and Participatory Method for Gaining Social Information for Project, M Putting People First Ociological Variabels in Rural Development. Oxford University

Chaniago, T.D. (1993).Sistem Manajemen (pengelolaan) dewasa ini dalam M. Wodzicka- Tomaszewska, I.M. Mastika, A. Djajanegara, S. Gardiner dan T.R. Wiradarya (ed) Produksi Kambing Doma Indonesia. Universitas Sebelas Maret,Surakarta

Choirijah. (2002). Evaluasi Pengendalian Kerusakan Pantai melalui Percontoan Desa Model Peelestarian Lingkungan Dan Pemanfaatn Pesisir (Studi Kasus : Desa Grinting, Kecamatan Bulukumba, Kabupaten Brebes, jawa Tengah). ThesisMagister IImu Lingkungan Undip Semarang

Dahuri, R.H. Jacub Rais dan Sapta Putra Ginting. (2001).Pengelolaan Sumber Daya Wilayah Pesisir dan Lautan Secara Terpadu. Pradnya Paramita. Jakarta

Dahuri, R. (2003).Keanekaragaman Hayati. Penerbit PT Gramedia Pustaka Utama.Jakarta

(2003). Perbankan Diminta Lebih Adil dalam Memberikan Kredit. Kompas 15 Desember 2003. http://www.Kompas.com/kompas-cetak/0312/15/finansial/743748

Daniel, M. (2001).Metode Penelitian Sosial Ekonomi. Bumi Aksara Jakarta

Davidson, Forbes and Pelternburg, M. (1993).Government and NGOs/CBOs Working Together for Better Cities. LHS Working Paper. Series No 6

Departemen Kelautan dan Perikanan. (2001). Pedoman Umum Pemberdayaan Ekonomi Masyarakat Pesisir. Jakarta

Dinas Perikanan dan Kelautan Kabupaten Pohuwato. (2018). Buku Statistik Perikanan Tangkap Kabupaten Bone Bolango Tahun 2018

Dinas Perikanan dan Kelautan Kabupaten Gorontalo. (2019). Data Statistik Kabupaten Gorotalo 2019.

Departemen Kelautan dan Perikanan. (2003). Pedoman Pengelolaan dan Perencanaan Tata Ruang Pesisir dan Laut. Ditjen Pesisir dan Pulau-pulau Kecil. Jakarta

Departemen Pertanian. (2004). Pengembangan Kawasan Agribisnis Berbasis Peternakan. Ditjen Peternakan Jakarta. www.bangnak.ditjennak.go.id/pdf 30 (tiga puluh) halaman diakses tanggal 7 Januari 2006 jam 08.00.

Departemen Kelautan dan Perikanan. (2005). Info Aktual: Kemiskinan Nelayan. Ditjen Pesisir dan Pulau- 
pulau Kecil. www.dkp.go.id/category.php 5 (lima) halaman diakses pada jam 19.00 tanggal 29 Januari 2006

Departemen Kelautan dan Perikanan. (2005). Info Aktual: Pemberdayaan Nelayan. Ditjen Pesisir dan Pulau-pulau Kecil. www.dkp.go.id/category.php5 (lima) halaman diakses pada jam 11.00 tanggal 05 Oktober 2007

Departemen Kelautan dan Perikanan. (2005). Penyusunan Rencana Tata Ruang Laut, Pesisir dan Pulaupulau Kecil Wilayah Perbatasan dengan Timor Leste. Ditjen P3K dan Dinas perikanan dan Kelautan Propinsi Gorontalo.

eRosari, B.B., Sri Widodo dan Masyuri.(2002). Variabelitas Konsumsi Pangan Pada Masyarakat NTT. Jurnal Argosains Berkala Penelitian Pasca Sarjana IImu-ilmu Pertanian UGM. Vol 151 Januari 2002 Hal 143-158

Devandra C., dan M, Burns.(1994). Produksi Kambing di daerah Tropis diterjamakanI.D.K.H Putra. Penerbit ITB Bandung

Dinas Peternakan kabupaten Gunung Kidul. (2001). Rencana Strategis Dinas Peternakan Kabupaten Gunung Kidul Tahun 2001-2005.

Yapanto, L. M., Musa, D. T., Tanipu, F., \& Suherman, S. (n.d.). The Impact of Covid-19 on Supply Chain Fisheries and Challenges by Fisherman in Indonesia. 22(10), 1360-1365.Technol. Forecast. Soc. Change 77: 1488- 1492.

Gjertsen, H., Hall, M., and Squires, D., 2010. Conservation and Management of Transnational Tuna Fisheries, Wiley Blackwell, New Jersey

Godet, M., and Roubelat, F., 1996. Creating The Future: The Use and Misuse of Scenarios. Long Range Planning. 29 (2): 164-171.

Gunter, P., 2010. The Blue Economy. Published by Paradigm Publication, TAOS New Mexico.

Gray, T., and Hatchard, J., 2008. A Complicated Relationship: Stakeholder Participation and the Ecosystems-based

Approach to Fisheries Management. Mar. Pol. 32: 158-168.

Human, BA, and Davies, A., 2010. Stakeholder Consultation During the Planning Phase of Scientific Programs. Mar. Pol. 34: 645-654

Idris, Pi., And Custer, J., 2012. Redesign of the Hatching Space Cooling System and Sea Water Made of Fiber. Student Scientific Journal 1 (1): 1401-1405

Kankaew, K., Yapanto, L. M., Waramontri, R., \& Arief, S. (2021). Uncertain Supply Chain Management

Supply chain management and logistic presentation: Mediation effect of competitive advantage. 9,255-264. https://doi.org/10.5267/j.uscm.2021.3.007

Yapanto, L. M., Tanipu, F., Paramata, A. R., \& Actors, E. (2020). THE EFFECTIVENESS OF FISHERY COOPERATIVE INSTITUTIONS. 17(25), 1329-1338.

Yapanto, L. M., \& Olilingo, F. Z. (2020). The contribution of the fisheries and marine sectors to improving regional income. 22(10), 1307-1319. 

